Original Research Paper

\title{
Meningkatkan Kemampuan Dasar Matematika Anak Melalui Macer (Matematika Ceria) di Desa Nijang
}

\author{
Yeyen Ermayani $^{*}$, Agil Al Idrus ${ }^{2}$ \\ ${ }^{1}$ Program Studi Pendidikan Matematika, Fakultas Keguruan dan Ilmu Pendidikan, Universitas Mataram, Mataram, Indonesia \\ ${ }^{2}$ Program Studi Pendidikan Biologi, Fakultas Keguruan dan Ilmu Pendidikan, Universitas Mataram, Mataram, Indonesia
}

DOI: https://doi.org/10.29303/jpmpi.v3i2.587

Sitasi:. Ermayani, Y., \& Idrus, A. A. (2020). Meningkatkan Kemampuan Dasar Matematika Anak Melalui Macer (Matematika Ceria) di Desa Nijang. Jurnal Pengabdian Magister Pendidikan IPA, 3(2)

\author{
Article history \\ Received: 25 Oktober \\ Revised: 15 Nopember \\ Accepted: 29 Desember \\ *Corresponding Author: Yeyen \\ Ermayani, Program Studi \\ Pendidikan Matematika, \\ Fakultas Keguruan dan Ilmu \\ Pendidikan, Universitas \\ Mataram, Mataram, Indonesia \\ Email: \\ yeyen.erma98@gmail.com
}

\begin{abstract}
Kegiatan ini bertujuan untuk meningkatkan kemampuan konsep matematika awal pada anak usia dini melalui pembelajaran matematika ceria. Matematika ceria adalah pembelajaran matematika yang mengajarkan anak anak untuk belajar matematika dengan menyenangkan dengan strategi pendekatan dan pembelajaran yang baik. Metode yang digunakan adalah Analisis data kualitatif dengan cara menganalisa data dari hasil catatan di lapangan atau kegiatan pembelajaran yang telah dilaksanakan. Pengajar sebagai kolaborator melakukan kegiatan dari awal hingga akhir. Hasil kegiatan tidak dapat mengeneralisasi pada setiap permasalahan. Hasil kegiatan ini dapat menyumbangkan pemikiran untuk membantu menjawab permasalahan. Dari kegiatan akhir yang telah dilaksankan ada peningkatan yang siknifikan dimana menurut kalkulasi umum pada seluruhnya tingkatan kelas 1 sampai dengan 3 memiliki peningkatan pemahaman sekitar $45 \%$ dan untuk tingkatan kelas 4 sampai dengan 6 peningkatan pemahaman $50 \%$. kalkulasi ini terbilang cukup baik untuk peningkatan pemahaman anak-anak pada konsep dasar matematika pada anak usia dini di Rumah Ilmu Desa Nijang.
\end{abstract}

Keywords: Kemampuan dasar anak; Anak-anak usia dini; Strategi pendekatan dan pembelajaran.

Pemperolehan nilai matematika dan sains

\section{Pendahuluan}

Pelajaran matematika masih di rasakan sebagai mata pelajaran yang menakutkan dan dianggap sulit oleh siswa Indonesia. Kesulitan tersebut hampir di rasakan oleh anak anak hampir di semua jenjang. Tidak jarang siswa merasa lebih baik tidak sekolah untuk menghindari pertemuan dengan pelajaran yang menakutkan itu (Nursalam, 2016). Kesulitan belajar siswa terhadap pelajaran matematika membawa dampak pada perolehan nilai mata pelajatan itu. Merosotnya nilai rata-rata perolehan siswa pada setiap ujian disebabkan karena rendahnya nilai matematika yang diperoleh. pada tingkat sekolah lanjutan dipengaruhi oleh penguasaan konsep matematika pada jenjang sebelumnya. Kemampuan matematika awal yang dimiliki sejak usia dini akan menentukan hasil kemampuan matematika pada jenjang berikutnya (Ramani \& Siegler, 2008). Kemampuan menghitung sangat penting untuk memperluas pemahaman kuantitatif. Temuan penelitian menunjukan bahwa kemampuan berhitung pada usia dini dapat memprediksi kemampuan berhitung di kemudian hari (Jordan, Glutting \& Watkins, 2010). Pendidikan sejak usia dini dapat meningkatkan kemampuan pada jenjang berikutnya (Rahmawati et al., 2015). Penelitian tindakan cocok untuk penelitian di bidang pendidikan, dalam 
lingkungan belajar mengajar untuk mengumpulkan informasi tentang bagaimana sekolah mereka beroperasi, bagaimana mereka mengajar, dan seberapa baik siswa mereka belajar. Informasi ini dikumpulkan dengan tujuan memperoleh wawasan, mengembangkan praktek reflektif, mempengaruhi perubahan positif di lingkungan sekolah dan praktik pendidikan pada umumnya, dan meningkatkan hasil siswa dan kehidupan orang-orang yang terlibat (Tripp, 2005).

Tujuan umum yang ingin dicapai dari matematika ceria ini adalah meningkatkan kemampuan dasar matematika anak anak pada jenjang awal. Selain itu pula memberi pengalaman baru dan menyenangkan untuk anak anak pada pembelajaran matematika anak yang terkesan kaku dan monoton.

\section{Metode}

Metode penelitian yang digunakan adalah Analisis data kualitatif dengan cara menganalisa data dari hasil catatan di lapangan atau kegiatan pembelajaran yang telah dilaksanakan serta hasil akhirnya. Penelitian ini di lakukan pada beberapa anak yang terpilih pada kegiatan akhir. Data data yang terkumpul menjadi modal utama untuk menghasilakan tingkatan pemahaman anak, data yang di ambil di bagi menjadi dua tingkatan yaitu tingkatan pertema dari kelas 1 sampai 3 dan tingkatan kedua dari kelas 4 sampai 6 . Total anak anak yang menjadi objek utamanya ada 18 orang anak.

\section{Hasil dan Pembahasan}

Pendidikan Anak Usia Dini sebagai awal jenjang pendidikan tentu sangat memiliki peran sangat penting yang akan menentukan keberhasilan pada jenjang pendidikan selanjutnya. Mendukung pernyataan tersebut adalah Bailey, dalam bukunya berjudul Journal Early Childhood Development, menyebutkan "Early childhood is a critical stage of development that forms the foundation for children's future well-being and learning". Usia dini merupakan periode kritis dalam memberikan pondasi yang akan berpengaruh terhadap pendidikan selanjutnya (Bailey, 2002)

Hal tersebut disebabkan pembelajaran matematika masih merupakan sesuatu yang dianggap menyeramkan. Kesulitan yang dihadapi saat belajar matematika menjadikan matematika sesuatu yang sering dianggap menakutkan dan menimbulkan tekanan pada siswa. Tekanan berupa kecemasan saat belajar matematika akan berpengaruh pada tingkat pemahamansiswa terhadap konsep-konsep matematika (Ulfiani rahman, 2015).

Kemampuan anak menjawab masih berdasarkan kemampuan menghapal tanpa memahami nilai dari lambang bilangan.Anak masih kesulitan membedakan dan membandingkan konsep banyak dan sedikit anak berfikir masih mengandalkan indera penglihatan, hampir semua siswa yang mengalami kesulitan belajar matematika disebabkan oleh lemahnya konsep perbandingan , akurasi bilangan, identifikasi nomor dan memory kerja yang lemah. (Gersten, Jordan, \& Flojo, 2014).

Rendahnya kemampuan matematika pada siswa di Indonesia disebabkan salah satunya adalah ketidakmampuan guru menciptakan suasana belajar yang menyenangkan dan interaksi yang aktif antara guru dan siswa. Pembelajaran matematika bukan lagi sebuah mata pelajaran yang seharusnya dapat membantu dalam pemecahan permasalahaan pada mata pelajaran lain, justru malah menjadi penghambat motivasi siswa untuk belajar.

Matematika ceria adalah pembelajaran matematika yang mengajarkan anak anak untuk belajar matematiaka dengan menyenangkan, metode pembelajaran yang di gunakan yaitu metode pembelajaran Fun Learning, pembelajaran ini pada umumnya di harapkan dapat memberi pengalaman yang berbeda untuk anak anak dalam belajar matematika, khususnya pada materi prinsip dasar matematika untuk anak anak usia dini. Dari beberapa pengalaman yang di temukan di lapangan, masih banyak anak anak yang mengalami kesulitan dalam memahami matematika, hal ini di karenakan masih kurangnya pemahaman terkait prinsip atau dasar dasar matematika yang menjadi modal utama anak anak untuk memahami pembelajaran pada tingkatan selanjutnya.

Berdasarkan hasil penelitiam yang didapat oleh (Maswar, 2019) menunjukkan bahwa untuk memotivasi siswa menyukai matematika dapat diterapkan strategi pembelajaran matematika menyenangkan siswa (MMS) berbasis metode permainan mathemagic, teka-teki matematis, dan cerita-cerita matematika yang menarik, menantang dan menghibur. Dengan demikian, pembelajaran di kelas matematika menjadi nyaman, dan tidak kaku. 
Selain itu, melalui metode-metode tersebut dapat merangsang siswa tertarik belajar matematika dan merangsang otak mereka untuk berpikir kreatif. Belajar menjadi terhibur, dan persepsi siswa terhadap matematika yang selama ini negatif karena dipandang rumit, jelimet, terlalu serius dan membosankan menjadi persepsi positif yakni matematika itu asyik, mudah, banyak manfaatnya, menghibur dan menyenangkan Hal ini sejalan dengan hasil penelitian yang didapat oleh (Abidin \& Tohir, 2019) menunjukkan bahwa pemilihan strategi yang sesuai dalam konstruksi rumus,penjelasan uraian masalah, informasi penting termasuk penyelesaian kendala yang ditemukan.

Adapun berdasarkan hasil penelitian yang didapat oleh (Mohammad Tohir, 2016a) menunjukkan bahwa untuk menjadikan siswa aktif dalam kegiatan pembelajaran, maka guru harus menerapkan sembilan hal yang dapat diterapkan pada kegiatan bertanya, yaitu (1) Mengenalkan suatufenomena menarik yang belum pernah dikenali oleh siswa sebelumnya, (2) Words in a question, (3) Guru memberikan contoh pertanyaan pancingan, (4) Guru membentuk kelompok belajar dalam kegiatan pengamatandan bertanya, (5) Guru dapat juga meminta siswa untuk bekerja dalam kelompok untuk membuat beberapa pertanyaan, (6) Guru mendampingi masing-masing siswa untuk membuat pertanyaan, (7) Completing What ifor What if not questions, (8) Questioning Breakfast, dan (9) Questioning Appraisal (Mohammad Tohir, 2016b).

Tahap utama yang dilakukan dalam kegiatan ini adalah pendekatan pada anak anak, dengan memberi motivasi dan rangsangan yang sedikit memberikan rasa nyaman untuk anak anak memulai kegiatan, tahap selanjutnya melakukan pembelajaran sebagaimana mestinya, dengan metode tanya jawab berupa soal dasar matematika, setelah menemukan permasalahan yang di hadapi, maka dari permasalahan tersebut adalah sebagai modal utama untuk menjelaskan kembali dengan cara bermain, untuk menimbulkan ketertarikan anak anak dalam materi yang di ajarkan, analisis kegiatan yang di lakukan setiap pembelajaran berlangsung sebagai landasan utama untuk melakukan pembelajaran pembelajaran selanjutnya.

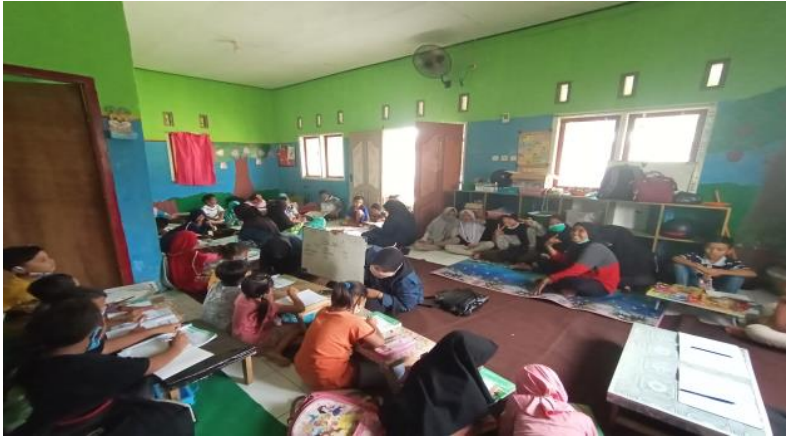

Gamabar 1. Pertemuan Pertama

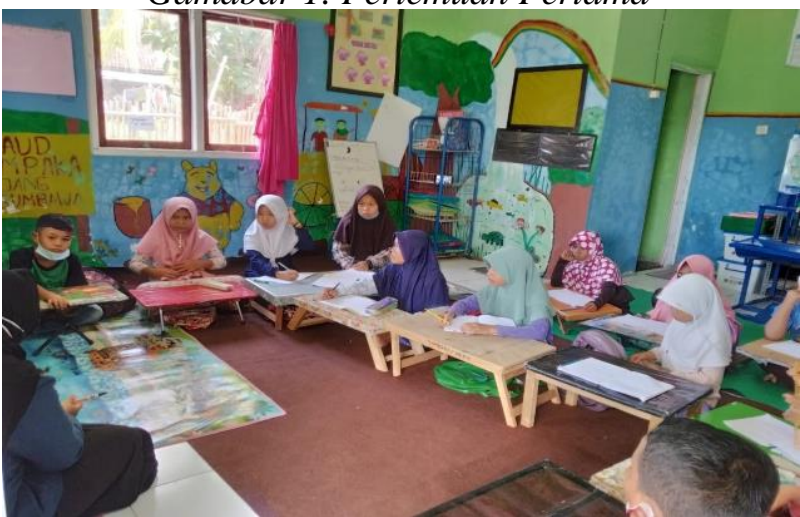

Gamabar 2. Salah satu kegiatan pembelajaran

Permasalahan-permasalahan yang di temukan pada anak melalui pembelajaran yang dilakukan adalah, pada tingkatan kelas 1 sampai 3 sekolah dasar, memang masih belum terbilang mampu memahami konsep dasar matematika seperti pertambahan dan pengurangan, namun dengan menggunakan pendekatan yang baik, mereka mampu memberikan respon dalam pembelajaran ketika di berikan beberapa soal dasar pertambahan dan pengurangan, dengan metode cerita dan memperagakan langsung ini melatih mereka untuk lebih mandiri dan mendapatkan pengalaman langsung.

Tingkatan kelas 4 sampai dengan 6 disini memiliki situasi yang cukup berbeda dari tingkatan sebelumnya, pendekatan yang dilakukan hampir sama namun pada tingkatan ini anak-anak sudah mampu bersikap mandiri, namun masih banyak permasalahan yang di temukan, seperti pada materi pembagian, ini pula di sebabkan anak anak belum memahami keterkaitan antara perkalian dan pembagian, padasahnya kedua materi ini saling berhubungan erat satu sama lain, ketika anak-anak di hadapkan dengan materi pembagian, mereka merasa kesulitan dalam menyelesaikannya. Maka dari itu di sini yang telah di lakukan adalah memberikan pemahaman dasar untuk anak-anak 
akan keterkaitan keduanya, dengan memberikan beberapa soal untuk memberi stimulasi untuk anak anak dan memberi pertanyaan untuk mengulas kembali pemahaman mereka terhap materi tersebut.

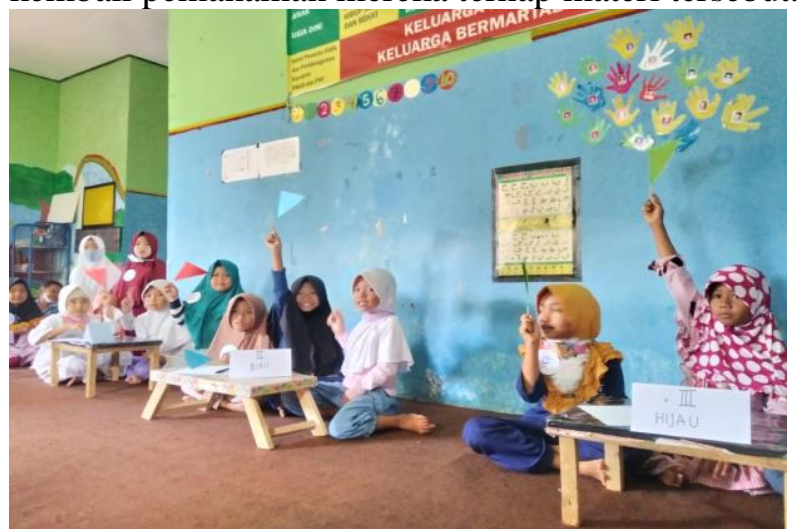

Gambar 3. Cerdas cermat tingkatan kelas 1 sampai 3

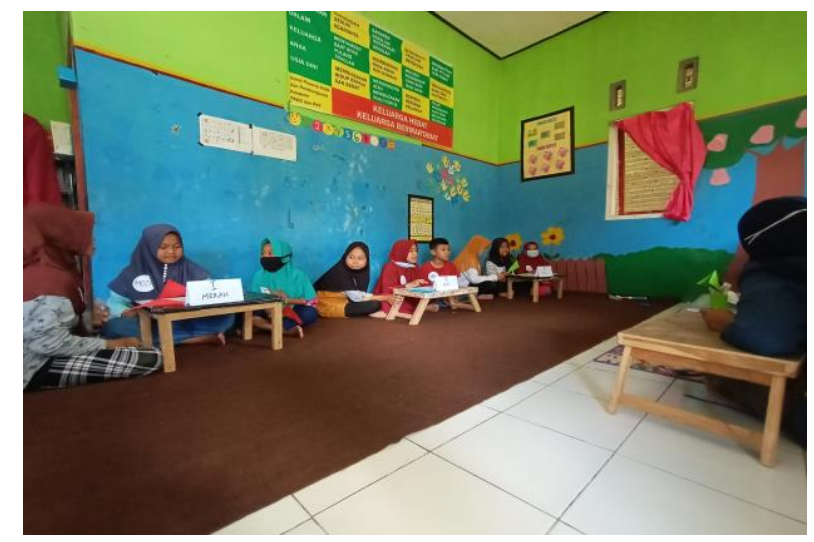

Gambar 4. Cerdas Cermat tingkatan kelas 4 sampai 6

Pada akhir kegiatan yang di lakukan, pada saat ini adalah evaluasi keseluruhan pemahaman anak anak akan konsep dasar matematika setelah dilaksanakannya pembelajaran selama kurang lebih 5 pekan, evaluasi tersebut berupa lomba ketangkasan cerdas cermat matematika, yang dimana kegiatan ini menjadi tahapan terakhir yang di lakukan untuk memperoleh data observasi dalam kegiatan ini, hasil akhir dari kegiatan ini adalah, dimana menurut kalkulasi umum pada seluruhnya tingkatan kelas 1 sampai dengan 3 memiliki peningkatan pemahaman sekitar $45 \%$ dan untuk tingkatan kelas 4 sampai dengan 6 peningkatan pemahaman $50 \%$. kalkulasi ini terbilang cukup baik untuk peningkatan pemahaman anak-anak pada konsep dasar matematika pada anak usia dini.

\section{Kesimpulan}

Pembelajaran pada anak usia dini yang masih pada fase praoperasional harus memperhatikan kebutuhan dan tingkat kenyamaan anak. Agar pembelajaran optimal perlu pendekatan yang baik untuk memberi kesan menyenangkan pada anak. Memahami permasalahan yang di hadapi setiap anak adalah hal yang harus di perhatikan terlebih dahulu, karena setiap anak memiliki tingkatan pemahaman yang berbeda dalam menerima setiap informasi yang diberikan, setiap pengajar harus memiliki strategi yang baik untuk menciptakan pengalaman pertama yang berbeda untuk anak anak usia dini, karena pengalaman pertma yang di terima anak-anak akan menentukan hasil dan pembelajaran yang baik untuk anak-anak.

\section{Ucapan Terima Kasih}

Ucapan terimakasih kepada pihak-pihak yang terlibat pada kegiatan ini yang pertama kepada Kepala Desa Nijang atas kesempatan dan kepercayaan yang diberikan untuk melaksanakan kegiatan ini, kedua pikah Yayasan Rumah Ilmu yang memberikan bimbingan, masukan, dan kerjasamanya selama pelaksanaan kegiatan, ketiga anak-anak desa Nijang yang selalu antusias dalam mengikuti pembelajaran matemtaika dan selalu memberikan semangatnya dalam mengikuti pembelajaran sampai akhir kegiatan, serta rekanrekan KKN yang ikut serta secara aktif selama pelaksanaan kegiatan. Tidak lupa pula ucapan terima kasih kepada dosen pembimbing lapangan bapak Prof. Dr. H. Agil Al Idrus. M.Si. yang telah sabar membimbing dalam penyelesain artikel ini tepat pada waktunya.

\section{Daftar Pustaka}

Abidin, Z., \& Tohir, M. (2019). Keterampilan Berpikir Tingkat Tinggi dalam Memecahkan Deret Aritmatika Dua Dimensi Berdasarkan Taksonomi Bloom. Alifmatika: Jurnal Pendidikan dan Pembelajaran Matematika, 1(1), 44-60.

Bailey, D. B. (2002). Are critical periods critical for early childhood education? The role of timing in early childhood pedagogy. Early 
Childhood Research Quarterly, 17(3), 281294. https://doi.org/10.1016/S08852006(02)00165-5

Gersten, R., Jordan, N. C., \& Flojo, J. R. (2014). Early Identification and Mathematics Difficulties, 38(4), 293-304.

Jordan, N. C., Glutting, J., \& Watkins, M. W. (2010). Validating a Number Sense Screening Tool for Use in Kindergarten and First Grade: Prediction of Mathematics Proficiency in Third Grade, 39(2), 181195.

Maswar, M. (2019). Strategi Pembelajaran Matematika Menyenangkan Siswa (MMS) Berbasis Metode Permainan Mathemagic, Teka-Teki dan Cerita Matematis. Alifmatika: Jurnal Pendidikan Dan Pembelajaran Matematika, 1(1), 28-43.

Nursalam, N. (2016). Diagnostik Kesulitan Belajar Matematika: Studi Pada Siswa Sd/Mi Di Kota Makassar. Lentera Pendidikan: Jurnal Ilmu Tarbiyah Dan Keguruan, 19(1), 1-15. https://doi.org/10.24252/lp.2016v19n1a1

Rahmawati, Vijaya, E. S., Puslitjakdikbud, P. U., Development, P., Mathematics, C., \& Pedagogy, M. (2015). International Science Achievement. 2016, 2015.

Ramani, G. B., \& Siegler, R. S. (2008). Promoting Broad and Stable Improvements in LowIncome Children's Numerical Knowledge Through Playing Number Board Games, 79(2), 375-394.

Tohir, Mohammad. (2016a). Menjadikan Para Siswa Aktif Bertanya dalam Kelas Matematika Berdasarkan Kurikulum 2013. Prosiding Seminar Nasional Matematika Dan Pembelajarannya, 249-263.

Tohir, Mohammad. (2016b). Making Students Actively Ask Questions in Mathematics Classes Based on Curriculum 2013. Proceedings of the National Mathematics Seminar and Learning, 249-263.

Tripp, D. (2005). Action research: a methodological introduction. Educação e Pesquisa, 31, 443-466. https://doi.org/10.1049/ipsen:20020540
Ulfiani rahman. (2015). Pengaruh Kecemasan dan Kesulitan belajar Matematika terhadap Hasil belajar Matematika Pada Siswa Kelas $X$ MA Negeri 1 Watampone Kabupaten Bone. Journal Matematika, 3, 85-102. 